\title{
SPECTROPHOTOMETRIC METHODS FOR THE QUANTIFICATION OF CARISOPRODOL USING FERRIC CHLORIDE, $O$-PHENANTHROLINE, AND $P$-NITROANILINE, SODIUM NITRITE AS ANALYTICAL REAGENTS
}

\author{
MURALI D ${ }^{1 *}$, PURNA CHANDRA RAO G ${ }^{2}$ \\ ${ }^{1}$ Department of Biochemistry, Acharya Nagarjuna University, N. Nagar, Guntur, Andhra Pradesh, India. ${ }^{2}$ Department of Chemistry, NRI
} Institute of Technology, Pothavarappadu, Agiripalli, Vijayawada, Andhra Pradesh, India. Email: murali.dadi@gmail.com

Received: 24 September 2018, Revised and Accepted: 02 November 2018

\section{ABSTRACT}

Objective: The present study represents the development of two spectrophotometric methods for the determination of carisoprodol (CCP) in pure and formulations using ferric chloride, $o$-phenanthroline, and p-nitroaniline (PNA), sodium nitrate as analytical reagents

Methods: The proposed spectrophotometric methods were developed based on oxidation of Fe ${ }^{3+}$ by CCP, and then, the resultant product was reacted with $o$-phenanthroline in acidic condition forms an orange-colored complex and diazotization of PNA followed by coupling with CCP in an alkaline medium forms yellow-colored complex.

Results: Under the optimized conditions, the absorbance of CCP concentration obeyed the Beer's law in the ranges of $10-60 \mu \mathrm{g} / \mathrm{mL}$ with good correlation coefficient values of 0.9992 and 0.9990 with the limit of detection values of 1.286 and $2.408 \mu \mathrm{g} / \mathrm{mL}$, respectively.

Conclusion: The proposed methods were successfully applied for the determination of CCP in pure and in their formulations.

Keywords: Ferric chloride, $o$-Phenanthroline, p-Nitroaniline, Sodium nitrate, Spectrophotometry, Analysis.

(C) 2019 The Authors. Published by Innovare Academic Sciences Pvt Ltd. This is an open access article under the CC BY license (http://creativecommons. org/licenses/by/4. 0/) DOI: http://dx.doi.org/10.22159/ajpcr.2019.v12i2.29902

\section{INTRODUCTION}

Carisoprodol (CCP) is a skeletal muscle relaxant belonging to monocarboxylic acids and derivatives class of organic compounds [1] that have both sedative and skeletal muscle relaxant effects [2]. The mechanism of CCP is not known exactly. Along with rest and physical therapy, CCP is also used in the treatment of injuries and painful musculoskeletal conditions [3,4]. CCP chemically known as [2-(carbamoyloxymethyl)-2-methylpentyl] N-propan2-ylcarbamate (Fig. 1). The detailed survey of literature revealed that few methods have been reported for the estimation of CCP by liquid chromatography-tandem mass spectrophotometry [5], gas chromatography [6,7], homogeneous immunoassay [8], highperformance thin-layer chromatography [9], liquid chromatography/ mass spectrophotometry [10], and ultraviolet (UV)-high-performance liquid chromatography [11]. The above reported chromatographic methods employed sophisticated and expensive instrumentation. Hence, UV-visible spectrophotometric methods are preferred for the precise, accurate, and cost-effective determination of pharmaceutical substances. There are three extractive spectrophotometric methods that have been reported for the assay of CCP in pure and pharmaceutical formulations [12]. However, the above methods were suffered from one or the other disadvantage such as poor sensitivity, unstable color, and rigid experimental conditions.

By considering into the above disadvantages of the reported methods, the present investigation was aimed to develop and validate some simple, sensitive, precise, accurate, and economical visible spectrophotometric methods

In the present investigation, two simple and sensitive visible spectrophotometric methods (method-A and method-B) were developed and validated for the analysis of CCP with broad linearity, good precision, and accuracy. These methods could be applied for the quantitative determination of the CCP in their tablet formulations.

\section{METHODS}

Instrumentation

An ELICO (Hyderabad, India) double beam model SL 244 digital spectrophotometer with $1 \mathrm{~cm}$ matched quartz cell was used for the spectral and absorbance measurements. A Coslab (Ambala Cantt, India) CLE-105 model water bath was used to control the temperature and a Shimadzu (Tokyo, Japan) electronic weighing balance, model BL $220 \mathrm{H}$, was used for weighing the samples.

\section{Chemicals and reagents}

All reagents and chemicals were of analytical reagent grade and used as received. All the solutions were prepared fresh daily using double distilled water. Aqueous solutions of $0.2 \%(w / v) o$-phenanthroline, $0.54 \%(w / v)$ ferric chloride, $0.2 \mathrm{M}(v / v)$ orthophosphoric acid (Merck Specialties Pvt., Ltd., Mumbai, India), $0.2 \mathrm{M} \mathrm{HCl}(v / v), 0.1 \%$ $p$-nitroaniline (PNA), and $0.4 \%(w / v)$ and $4 \%(w / v)$ sodium hydroxide (SD-Fine Chemicals Ltd., Mumbai, India) prepared in the usual way.

\section{Stock and working standard solutions}

Analytically pure CCP was obtained as a gift sample from the Aurobindo Laboratories Pvt., Ltd., (India) and was used as received. The stock solution of CCP was prepared by dissolving $100 \mathrm{mg}$ of CCP in $20 \mathrm{ml}$ of methanol in a $100 \mathrm{ml}$ volumetric flask and then make up to the mark with distilled water $(1.0 \mathrm{mg} / \mathrm{ml})$. The stock solution was diluted stepwise with the same distilled water to obtain working standard solutions of concentration of $200 \mu \mathrm{g} / \mathrm{mL}$ for methods A and B, respectively.

\section{General assay procedure}

Method-A

Delivered aliquots of standard CCP $(0.5-3.0 \mathrm{ml}, 200 \mu \mathrm{g} / \mathrm{ml})$ into $10 \mathrm{ml}$ calibrated tubes. To each tube, $1.0 \mathrm{ml}$ of $0.2 \% 0$-PHEN was added followed by $1.0 \mathrm{ml}$ of $0.54 \% \mathrm{FeCl}_{3}$ solution. The contents of the tubes were mixed well and the resulting solution was heated for $15 \mathrm{~min}$ at $100^{\circ} \mathrm{C}$, and then, 
$2.0 \mathrm{ml}$ of $0.2 \mathrm{M}$ orthophosphoric acid was added. The volume in each tube was made up to the mark with distilled water and the absorbance of the colored solution was measured at $495 \mathrm{~nm}$ against a reagent blank.

\section{Method-B}

To a set of $10 \mathrm{ml}$ calibrated tubes, aliquot volumes $(0.5-3.0 \mathrm{ml})$ of CCP standard solution $(200 \mu \mathrm{g} / \mathrm{ml})$ were quantitatively transferred. To each tube, $0.8 \mathrm{ml}$ of $0.1 \%$ PNA followed by $1.0 \mathrm{ml}$ of $0.4 \% \mathrm{NaNO}_{2}$ were added and mixed well. The solutions were kept aside for $20 \mathrm{~min}$. Then, $2.0 \mathrm{ml}$ of $4 \% \mathrm{NaOH}$ was added and again kept aside for $30 \mathrm{~min}$. After the specified time, the tubes were made up to volume with distilled water. The absorbance was measured at $445 \mathrm{~nm}$ against a reagent blank.

In both the methods, the calibration graphs were plotted against the absorbance with the final concentration of the CCP $(\mu \mathrm{g} / \mathrm{mL})$.

Procedure for the assay of CCP in pharmaceutical formulations (tablets)

The tablet formulation of CCP, Pain 0 Soma ${ }^{\circledR}$ (HAB Pharmaceuticals and Research Ltd., Dehradun, India) labeled to contain $250 \mathrm{mg}$ and $350 \mathrm{mg}$

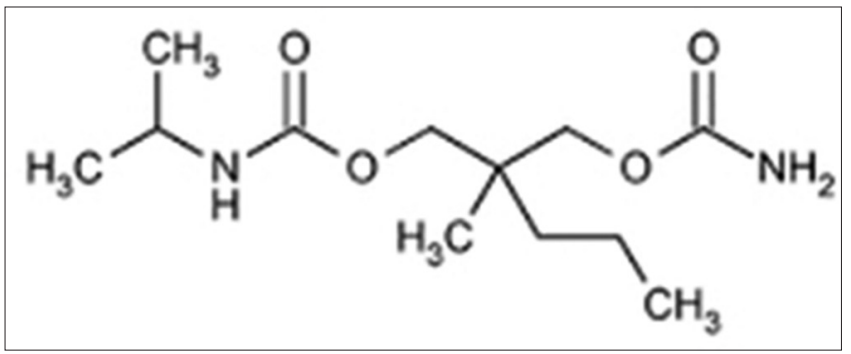

Fig. 1: Structure of carisoprodol

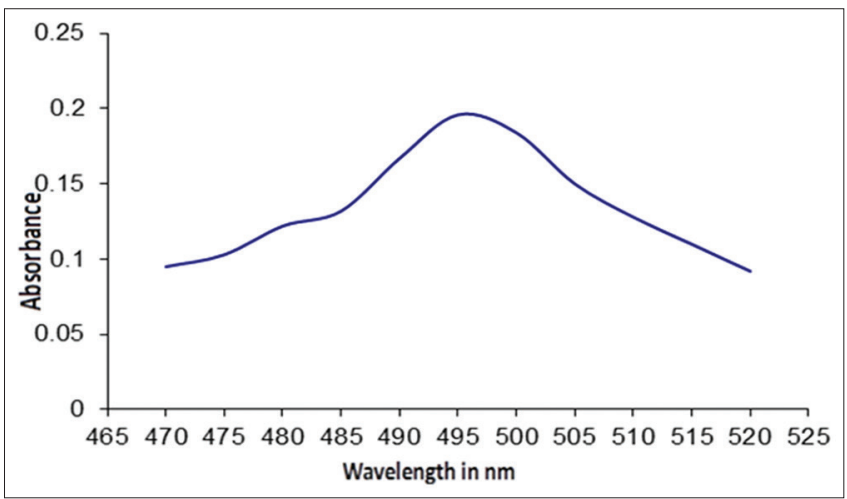

Fig. 2: Absorption spectrum of carisoprodol with $\mathrm{FeCl}_{3}$ and $o$-phenanthroline was purchased from a local pharmacist. 10 tablets of each were accurately weighed, finely powdered, and mixed well. A portion of the powder equivalent to $100 \mathrm{mg}$ of CCP was transferred into $100 \mathrm{ml}$ volumetric flasks, about $30 \mathrm{ml}$ methanol was added and the contents of the flask were sonicated for $15 \mathrm{~min}$. The volume was made with distilled water, mixed, and filtered using Whatman No. 1 filter paper. Aliquots covering the working concentration ranges of proposed methods were prepared with distilled water. The procedures described under general analytical procedure were followed. The nominal contents of the CCP in tablets were calculated using the corresponding calibration curve or regression equation.

\section{RESULTS AND DISCUSSION}

\section{Method-A}

The reaction of $\mathrm{FeCl}_{3}$ and $o$-phenanthroline with the amino group has been reported for some amino group containing drugs. The results of those reactions demonstrated that the combination of $\mathrm{FeCl}_{3}$ and $o$-phenanthroline is one of the good chromogenic reagents in the development of spectrophotometric methods for the determination of many drugs containing amine groups [13-18]. In this present developed method, CCP was reacted with ferric chloride under suitable experimental conditions which convert ferric chloride into ferrous salt, the amount of conversion correlated to the drug concentration. These ferrous ions react with $o$-phenanthroline to form orange-red-colored chromogen (Scheme. 1) with maximum absorption at $495 \mathrm{~nm}$ (Fig. 2) by obeying Beer's law in the concentration range of $10-60 \mu \mathrm{g} / \mathrm{mL}$.

\section{Method-B}

PNA is a well-known reagent to react with amines to form the stable diazo complex. In the presence of sodium nitrite and Hcl, PNA) acts as a chromogenic reagent, which has been used for the determination of various drugs containing amino groups [14,18-22]. In the present investigation, PNA undergoes diazotization followed by coupling with CCP in the alkaline medium by the formation of the yellow-colored complex (Scheme. 2) with $\lambda$ maximum at $445 \mathrm{~nm}$ (Fig. 3) by obeying Beer's law in the concentration range of $10-60 \mu \mathrm{g} / \mathrm{mL}$.

\section{OPTIMIZATION OF THE EXPERIMENTAL CONDITIONS}

Method-A

Various factors affect the reaction between the CCP and reagents including $\mathrm{FeCl}_{3}, o$-PHEN, and $o$-phosphoric acid concentrations, temperature, and heating time. These were studied to optimize the reaction conditions and to give maximum absorbance. All these optimum values of various factors were maintained throughout the experiment.

\section{Effect of FeCl3 volume}

The effect of $0.54 \% \mathrm{FeCl}_{3}$ on the absorbance of the orange-colored complex was studied in the range of $0.5-3.0 \mathrm{~mL}$. The absorbance of the complex increased with the increase in the volume of $\mathrm{FeCl}_{3}$ up to $1.0 \mathrm{~mL}$. Further,

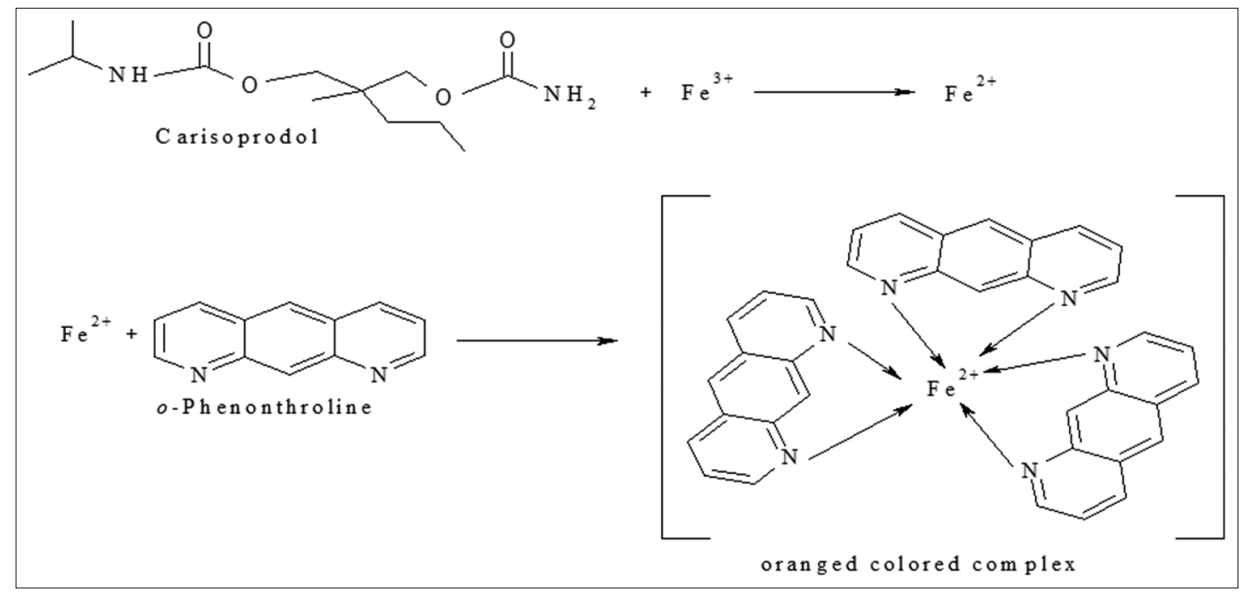

Scheme 1: Reaction of carisoprodol with $\mathrm{FeCl}_{3}$ and $o$-phenanthroline 


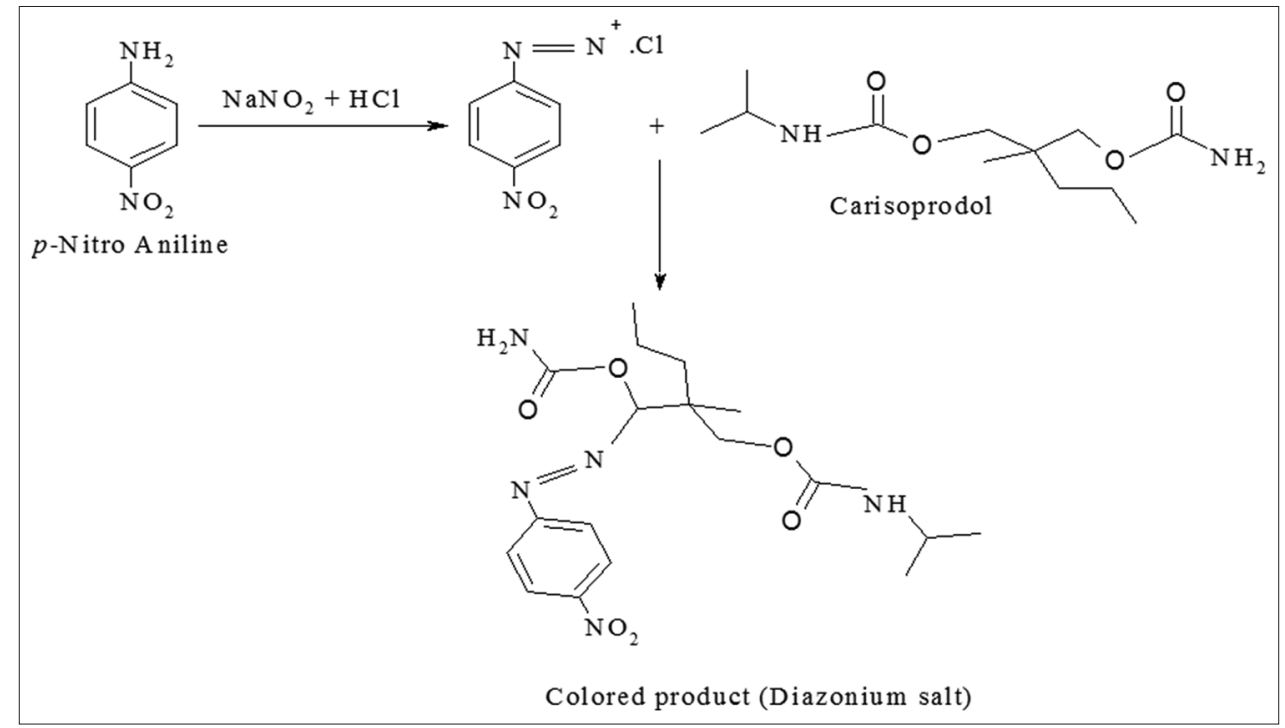

Scheme. 2: Reaction of carisoprodol with PNA

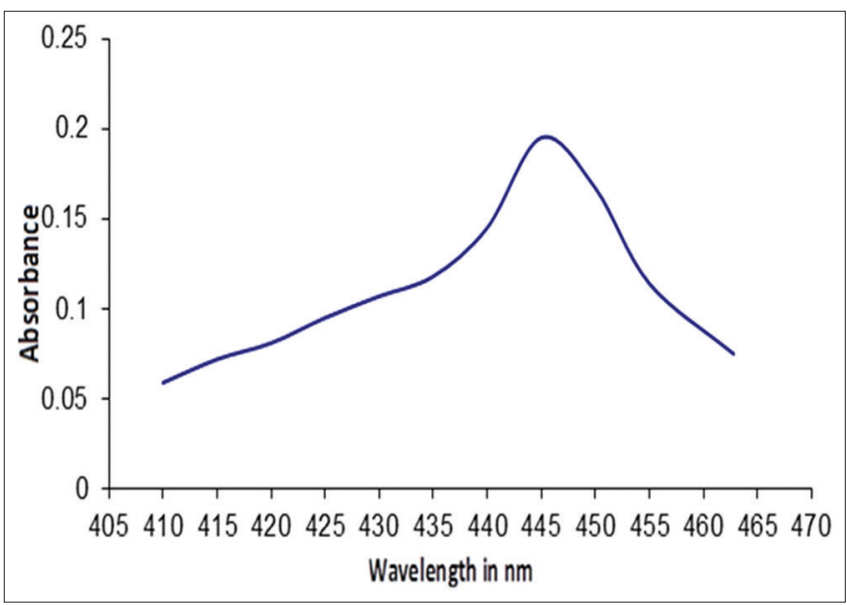

Fig. 3: Absorption spectrum of carisoprodol with p-nitroaniline and $\mathrm{NaNO}_{2}$

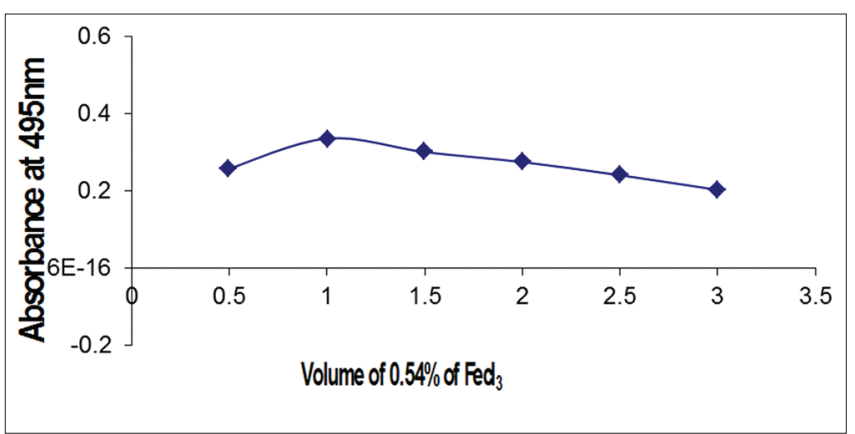

Fig. 4: Effect of the volume of $\mathrm{FeCl}_{3}$

addition of $\mathrm{FeCl}_{3}$ showed a decrease in the absorbance. Therefore, $1.0 \mathrm{~mL}$ of $0.54 \% \mathrm{FeCl}_{3}$ was considered as an optimum value (Fig. 4).

\section{Effect of o-phenanthroline concentration}

The effect of the concentration of $o$-phenanthroline was studied by conducting reaction between $10 \mu \mathrm{g} / \mathrm{mL} \mathrm{CCP}, 1 \mathrm{~mL}$ of $\mathrm{FeCl}_{3}$ and varying volumes $(0.5-3.0 \mathrm{ml})$ of $0.2 \% o$-PHEN and $2.0 \mathrm{ml}$ of $0.2 \mathrm{M} \mathrm{o}$-phosphoric acid. The reaction indicates that the absorbance of the $\mathrm{CCP}-\mathrm{FeCl}_{3}$ and $o$-PHEN complex was increased by increasing the volume of $0.2 \%$ $o$-PHEN up to $0.9 \mathrm{ml}$; later, it became constant at $1.0 \mathrm{~mL}$. Further

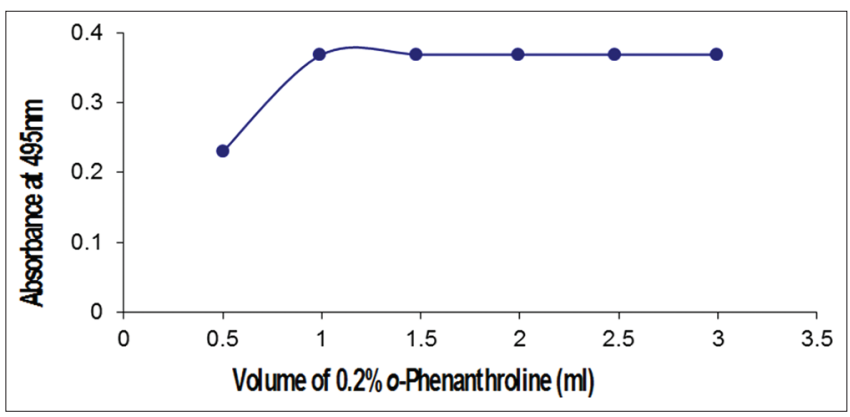

Fig. 5: Effect of the concentration of $o$-phenanthroline

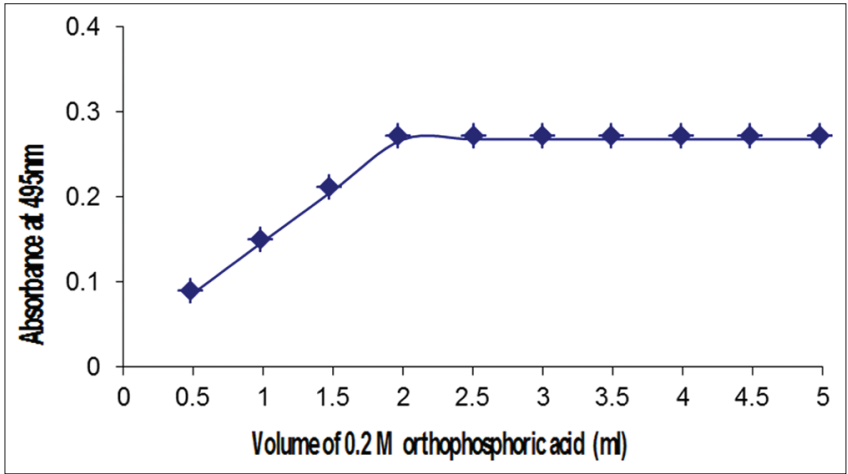

Fig. 6: Effect of the concentration of $o$-phosphoric acid

increase in the volume, there was no change in the absorbance (Fig. 5). Therefore, $1 \mathrm{~mL}$ of $0.2 \% o$-PHEN solution was chosen as the optimal volume for the development of the colored complex.

Effect of the concentration of orthophosphoric acid

The concentration of $0.2 \mathrm{M}$ orthophosphoric acid effect on the absorbance of the orange-colored complex was studied in the range of $0.5-5.0 \mathrm{ml}$. The absorbance increased with the increasing the volume of orthophosphoric acid and became constant at $2.0 \mathrm{ml}$. Further, addition of orthophosphoric acid did not show any change in the absorbance (Fig. 6).

\section{Effect of temperature}

The effect of the temperature on the orange-colored complex was studied between the temperatures $30-110^{\circ} \mathrm{C}$. The maximum absorbance 
was attained when the temperature reached $100^{\circ} \mathrm{C}$. Further increasing the temperature $>100^{\circ} \mathrm{C}$, the intensity of the color and the absorbance started to decrease (Fig. 7).

\section{Effect of time}

Time also one of the important factors which affect chemical reactions. In the present investigation, the effect of heating time on the formation of the orange-colored complex was also studied and optimized. At room temperature, the intensity of the color increased by the increasing the time, maximum absorbance was obtained at $15 \mathrm{~min}$ and remained constant for $30 \mathrm{~min}$. After $30 \mathrm{~min}$ of the time interval, the increase in the heating time did not cause any change in intensity of color (Fig. 8).

\section{Method-B}

In this method, PNA carried out diazotization reaction with $\mathrm{NaNO}_{2}$ under acidic conditions followed by coupling with the CCP. The experimental conditions were optimized by studying the effect of various parameters such as volume and concentrations of PNA, $\mathrm{NaNO}_{2}$, and $\mathrm{NaOH}$ for the maximum color development and the time required for diazotization and diazo coupling

\section{Effect of the concentration of $0.1 \%$ PNA}

To the study of the effect of the concentration of $0.1 \% p$-nitroaniline for yellow-colored development, different volumes $(0.2-2.0 \mathrm{ml})$ of $0.1 \%$ PNA were mixed with different volumes of CCP $(10 \mu \mathrm{g} / \mathrm{mL})$ and followed by $1.0 \mathrm{ml}$ of $0.4 \% \mathrm{NaNO}_{2}$, and then, $2.0 \mathrm{ml}$ of $4 \% \mathrm{NaOH}$ was added. The study indicates that the addition of $0.8 \mathrm{ml}$ of $0.1 \%$ PNA gave the maximum absorbance, which remained constant up to $2.0 \mathrm{ml}$. Therefore, $0.8 \mathrm{ml}$ of the $0.1 \%$ PNA was chosen for the determination of the CCP for the present experiment (Fig. 9).

\section{Effect of the volume of NaNO}

The effect of the volume of $0.4 \% \mathrm{NaNO}_{2}$ was studied during the formation of yellow color. This study carried out by addition of an aliquot of CCP containing $10 \mu \mathrm{g} / \mathrm{ml}$ to different volumes (0.5-3.0 ml) of $0.4 \% \mathrm{NaNO}_{2}$ and $0.8 \mathrm{ml}$ of $0.1 \%$ PNA and then $2.0 \mathrm{ml}$ of $0.4 \% \mathrm{NaOH}$. The results were shown that the maximum absorbance was attained with

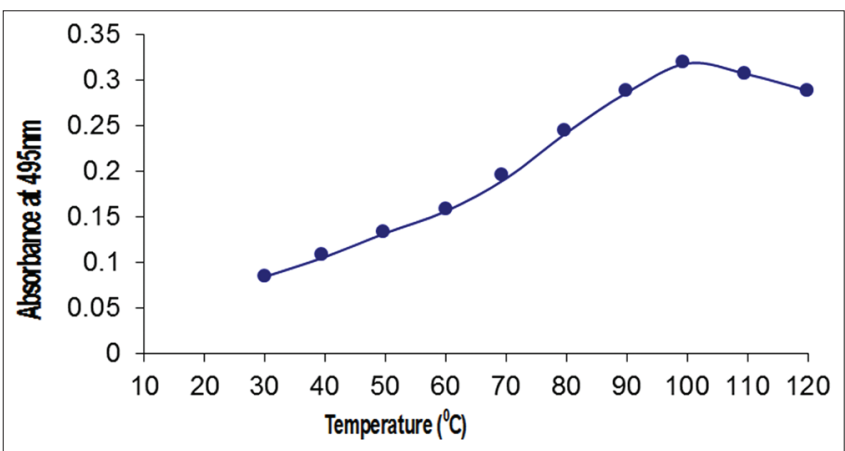

Fig. 7: Effect of temperature

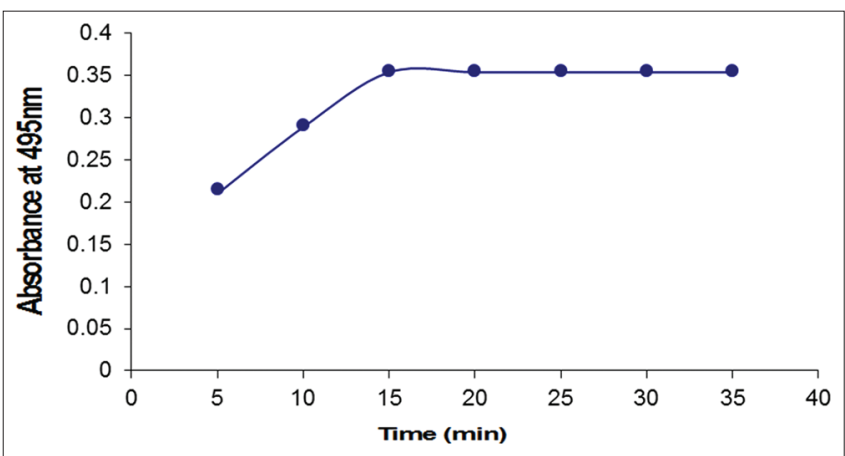

Fig. 8: Effect of time
$1.0 \mathrm{ml}$ of $0.4 \% \mathrm{NaNO}_{2}$. Further, addition of $\mathrm{NaNO}_{2}$ showed decrease in the absorbance. Therefore, $1.0 \mathrm{ml}$ of $0.4 \% \mathrm{NaNO}_{2}$ was used throughout the experiment (Fig. 10).

\section{Effect of time for diazotization}

To study the effect of time for diazotization, $1 \mathrm{~mL}$ of CCP $(10 \mu \mathrm{g} / \mathrm{mL})$ and $0.8 \mathrm{ml}$ of $0.1 \%$ PNA followed by $1.0 \mathrm{ml}$ of $0.4 \% \mathrm{NaNO}_{2}$ were added and mixed well. Later, the solutions were kept aside for $20 \mathrm{~min}$. Color intensity was obtained maximum at $20 \mathrm{~min}$. Further, increase in time no effect on diazotization. Hence, 20 min was chosen as the optimum time for diazotization (Fig. 11)

\section{Effect of the volume of $\mathrm{NaOH}$}

The effect of the volume of $4 \%$ sodium hydroxide on yellow color formation was studied by addition of different volumes $(0.5-4.0 \mathrm{ml})$ of $4 \%$ sodium hydroxide to an aliquot of CCP $(10 \mu \mathrm{g} / \mathrm{ml})$ and mixed well then added $0.8 \mathrm{ml}$ of $0.1 \%$ PNA followed by $1.0 \mathrm{ml}$ of $0.4 \% \mathrm{NaNO}_{2}$ to that mixture. The solutions were kept aside for $20 \mathrm{~min}$. The results are presented in Fig. 12, which indicate that the addition of $2.0 \mathrm{ml}$ of $4 \%$ $\mathrm{NaOH}$ gave the maximum absorbance, which remained constant up to

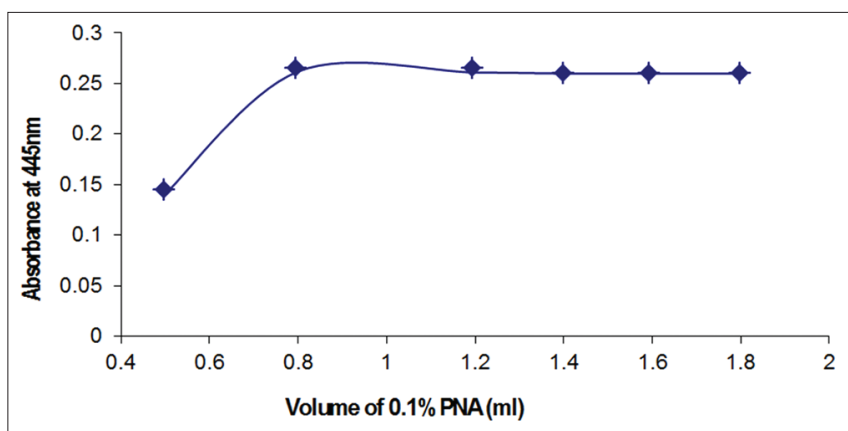

Fig. 9: Effect of the concentration of p-nitroaniline

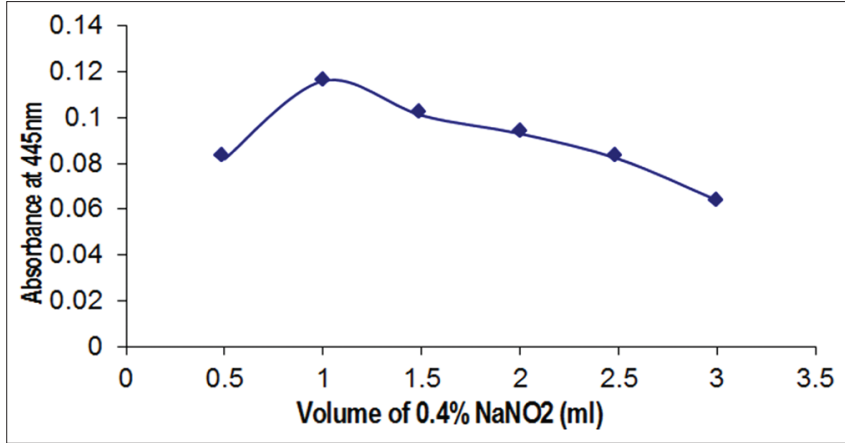

Fig. 10: Effect of the volume of $\mathrm{NaNO}_{2}$

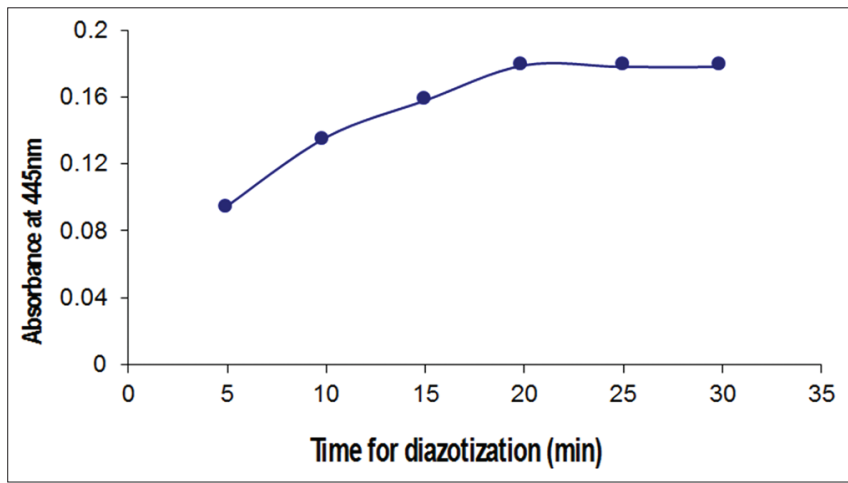

Fig. 11: Effect of time for diazotization 
$3.0 \mathrm{ml}$ later started to decrease. Therefore, $2.0 \mathrm{ml}$ of the $4 \% \mathrm{NaOH}$ was chosen for the quantification of the CCP throughout the experiment.

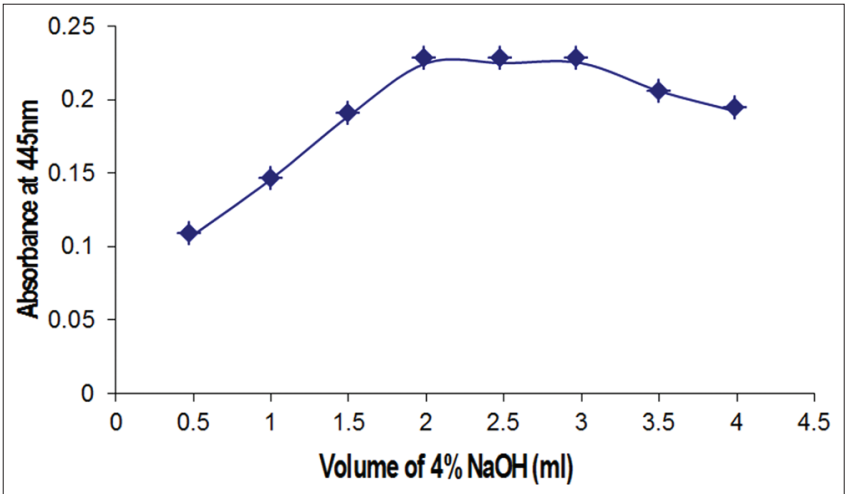

Fig. 12: Effect of the volume of $\mathrm{NaOH}$

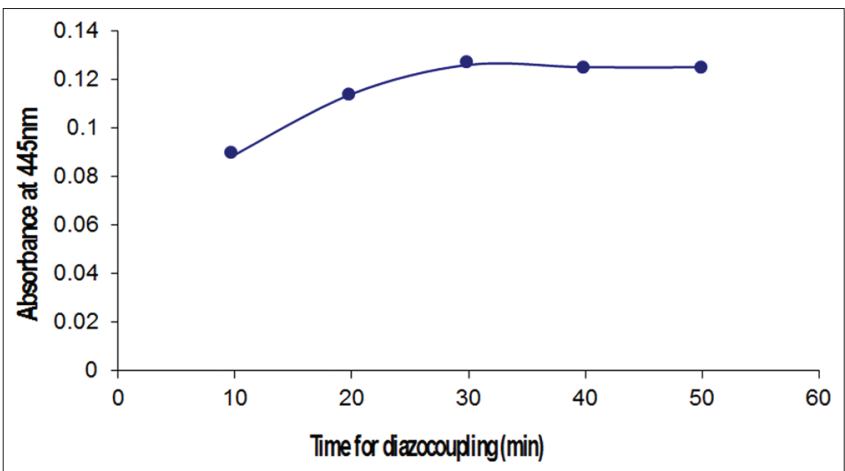

Fig. 13: Effect of time for diazo coupling

Table 1: Optical and regression characteristics of the proposed methods

\begin{tabular}{lll}
\hline Parameters & Method-1 & Method-2 \\
\hline$\lambda$ max & 495 & 445 \\
Beer's limit $(\mu \mathrm{g} / \mathrm{mL})$ & $10-60$ & $10-60$ \\
Molar absorptivity $\left(\mathrm{L}\right.$ mole- $\left.1 \mathrm{~cm}^{-1}\right)$ & $2.874 \times 10^{3}$ & $7.078 \times 10^{3}$ \\
Sandell's sensitivity $\left(\mu \mathrm{g} \mathrm{cm}{ }^{-2} / 0.001\right.$ & 0.2032 & 0.1960 \\
Absorbance unit) & & \\
Stability of colored products $(\mathrm{mins})$ & 50 & 70 \\
Regression equation $(\mathrm{Y}=\mathrm{mx}+\mathrm{c})^{* *}$ & & \\
$\quad$ Slope $(\mathrm{m})$ & 0.005 & 0.005 \\
$\quad$ Intercept $(\mathrm{c})$ & -0.0016 & 0.0030 \\
$\quad$ Regression coefficient $\left(\mathrm{r}^{2}\right)$ & 0.9992 & 0.9990 \\
$\quad \mathrm{LOD}(\mu \mathrm{g} / \mathrm{mL})$ & 1.286 & 2.408 \\
$\mathrm{LOQ}(\mu \mathrm{g} / \mathrm{mL})$ & 3.898 & 7.298 \\
\hline
\end{tabular}

$* * \mathrm{Y}=\mathrm{mx}+\mathrm{c}$, Where $\mathrm{y}$ is the absorbance and $\mathrm{x}$ is the concentration of drug in $\mu \mathrm{g} / \mathrm{mL}$. LOD: Limit of detection, LOQ: Limit of quantification

\section{Effect of time for diazo coupling}

To study the effect of time for diazo coupling, $1 \mathrm{~mL}$ of CCP $(10 \mu \mathrm{g} / \mathrm{mL})$ and $0.8 \mathrm{ml}$ of $0.1 \%$ PNA followed by $1.0 \mathrm{ml}$ of $0.4 \% \mathrm{NaNO}_{2}$ were added and mixed well. The solutions were kept aside for $20 \mathrm{~min}$. Then, $2.0 \mathrm{ml}$ of $4 \% \mathrm{NaOH}$ was added and again kept aside for $30 \mathrm{~min}$. Diazo coupling was completed at $30 \mathrm{~min}$. Hence, $30 \mathrm{~min}$ was chosen as optimum time (Fig. 13).

\section{VALIDATION OF THE DEVELOPED METHODS}

The developed methods were validated by following the ICH guidelines [23]. Various parameters including linearity, sensitivity, precision, accuracy, and robustness were studied.

\section{Linearity}

Linearity was studied in the concentration range from 10 to $60 \mu \mathrm{g} / \mathrm{mL}$ for methods - A and B, respectively. The drug showed good linearity in the tested range. The regression coefficient values for methods - A and B were found to be $>0.9989$. The obtained results have a good and dynamic linearity range of the developed methods.

\section{Sensitivity}

The sensitivity of the proposed methods was estimated in terms of Sandell's sensitivity, limit of quantitation, limit of detection, and molar absorptivity. The results are presented in Table 1, the results showed the high sensitivity of the developed methods.

\section{Accuracy and precision}

Precision and accuracy were investigated by analyzing different concentrations of CCP $(10,30$, and $60 \mu \mathrm{g} / \mathrm{ml})$ - for both methods (methods - A and B) in five independent replicates on the same day (intraday precision and accuracy) and on 3 consecutive days (interday precision and accuracy). The data are represented as the relative standard deviation (\%RSD) and percent recovery for precision and accuracy, respectively. The results have shown in Tables 2 and 3. Low RSD $(<1.0)$ values and good recovery values for intra- and interday analysis show good precision and accuracy data of the proposed methods (methods - A and B), respectively.

\section{RECOVERY STUDIES}

The accuracy of the proposed methods was further determined by the standard addition method. A known amount of CCP at three different levels $(5,100$, and $150 \%)$ was added to the pre-analyzed sample solution and the amount of CCP was estimated by the reported methods. The results were reported as the RSD and percent recovery are shown in Table 4. The recovery studies showed that there was no interference from excipients in the determination of the CCP by the proposed methods.

\section{Robustness}

The robustness of the proposed methods was studied by making small changes in the experimental parameters at two different concentration levels $(10$ and $60 \mu \mathrm{g} / \mathrm{mL})$. The results are presented in Table 5. The results showed that the slight changes did not adversely influence the absorbance intensity.

Table 2: Intraday precision and accuracy

\begin{tabular}{|c|c|c|c|c|c|}
\hline \multirow[t]{2}{*}{ Method } & \multicolumn{2}{|c|}{ Amount of CCP $(\mu \mathrm{g} / \mathrm{mL})$} & \multirow[t]{2}{*}{ RSD (\%) } & \multirow[t]{2}{*}{ Recovery (\%) } & \multirow[t]{2}{*}{ Error (\%) } \\
\hline & Taken & Found ${ }^{*} \pm S D$ & & & \\
\hline \multirow[t]{3}{*}{1} & 10 & $10.035 \pm 0.047$ & 0.473 & 100.35 & 0.35 \\
\hline & 30 & $30.030 \pm 0.062$ & 0.209 & 100.10 & 0.10 \\
\hline & 60 & $60.020 \pm 0.057$ & 0.095 & 100.03 & 0.03 \\
\hline \multirow[t]{3}{*}{2} & 10 & $10.003 \pm 0.025$ & 0.259 & 100.03 & 0.03 \\
\hline & 30 & $30.015 \pm 0.040$ & 0.135 & 100.05 & 0.05 \\
\hline & 60 & $60.016 \pm 0.066$ & 0.110 & 100.02 & 0.02 \\
\hline
\end{tabular}

*Average five determinations. CCP: Carisoprodol, SD: Standard deviation, RSD: Relative standard deviation 


\section{APPLICATION OF THE PROPOSED METHODS TO ANALYSIS OF CCP IN TABLET FORMULATIONS}

From the above-mentioned results, the proposed methods gave satisfactory results with CCP in bulk. Therefore, the proposed methods were successfully applied for the determination of CCP in their formulations. The results are shown in Table 6. The percent recovery and \%RSD clearly showed no interference of any excipients of formulation, thus proving accuracy and precision in the quantification of CCP by both methods.

Table 3: Interday precision and accuracy

\begin{tabular}{|c|c|c|c|c|c|}
\hline \multirow[t]{2}{*}{ Method } & \multicolumn{2}{|c|}{ Amount of CCP $(\mu \mathrm{g} / \mathrm{mL})$} & \multirow[t]{2}{*}{ RSD (\%) } & \multirow[t]{2}{*}{ Recovery (\%) } & \multirow[t]{2}{*}{ Error (\%) } \\
\hline & Taken & Found ${ }^{*} \pm$ SD & & & \\
\hline \multirow[t]{3}{*}{1} & 10 & $10.035 \pm 0.067$ & 0.675 & 100.35 & 0.35 \\
\hline & 30 & $30.036 \pm 0.059$ & 0.199 & 100.12 & 0.12 \\
\hline & 60 & $59.991 \pm 0.015$ & 0.026 & 99.98 & -0.02 \\
\hline \multirow[t]{3}{*}{2} & 10 & $10.006 \pm 0.086$ & 0.864 & 100.06 & 0.06 \\
\hline & 30 & $30.013 \pm 0.050$ & 0.168 & 100.04 & 0.04 \\
\hline & 60 & $59.998 \pm 0.012$ & 0.020 & 99.99 & -0.01 \\
\hline
\end{tabular}

*Average five determinations. CCP: Carisoprodol, SD: Standard deviation, RSD: Relative standard deviation

Table 4: Results of recovery studies by standard addition technique

\begin{tabular}{|c|c|c|c|c|c|}
\hline \multirow[t]{2}{*}{ Method } & \multicolumn{2}{|c|}{ Amount of CCP mg } & \multirow[t]{2}{*}{ Found* } & \multirow[t]{2}{*}{ RSD (\%) } & \multirow[t]{2}{*}{ Recovery (\%) } \\
\hline & Tablet & Spiked & & & \\
\hline \multirow[t]{3}{*}{1} & 10 & 5 & 14.992 & 0.619 & 99.94 \\
\hline & 10 & 10 & 20.005 & 0.055 & 100.02 \\
\hline & 10 & 15 & 25.006 & 0.046 & 100.03 \\
\hline \multirow[t]{3}{*}{2} & 10 & 5 & 15.018 & 0.131 & 100.08 \\
\hline & 10 & 10 & 20.022 & 0.116 & 100.11 \\
\hline & 10 & 15 & 25.007 & 0.032 & 100.29 \\
\hline
\end{tabular}

*Average of three determinations, CCP: Carisoprodol, RSD: Relative standard deviation

Table 5: Results of robustness of the proposed methods

\begin{tabular}{|c|c|c|c|c|c|c|}
\hline \multirow[t]{2}{*}{ Method } & \multirow[t]{2}{*}{ Parameter } & \multicolumn{2}{|c|}{ Concentration of CCP $(\mu \mathrm{g} / \mathrm{ml})$} & \multirow[t]{2}{*}{ SD } & \multirow[t]{2}{*}{ Recovery (\%) } & \multirow[t]{2}{*}{ RSD (\%) } \\
\hline & & Taken & Found* & & & \\
\hline \multirow[t]{9}{*}{1} & Volume of $0.2 \%$ & 10 & 10.01 & 0.032 & 100.10 & 0.323 \\
\hline & O-PHEN $(1.0 \pm 0.1 \mathrm{ml})$ & 60 & 59.99 & 0.025 & 99.98 & 0.042 \\
\hline & Volume of $0.54 \% \mathrm{FeCl}_{3}(1.0 \pm 0.1 \mathrm{ml})$ & 10 & 9.99 & 0.007 & 99.90 & 0.070 \\
\hline & & 60 & 60.01 & 0.029 & 100.01 & 0.049 \\
\hline & Volume of $0.2 \mathrm{M} \mathrm{H}_{3} \mathrm{PO}_{4}(2.0 \pm 0.2 \mathrm{ml})$ & 10 & 10.02 & 0.041 & 100.20 & 0.414 \\
\hline & Temperature & 10 & 10.03 & 0.051 & 100.30 & 0.513 \\
\hline & $\left(100 \pm 5^{\circ} \mathrm{C}\right)$ & 60 & 60.01 & 0.025 & 100.01 & 0.042 \\
\hline & Boiling time & 10 & 10.02 & 0.037 & 100.20 & 0.373 \\
\hline & $(15 \pm 2 \mathrm{~min})$ & 60 & 60.01 & 0.033 & 100.01 & 0.056 \\
\hline \multirow[t]{9}{*}{2} & Volume of $0.1 \%$ PNA $(0.8 \pm 0.1 \mathrm{ml})$ & 10 & 9.96 & 0.033 & 99.60 & 0.336 \\
\hline & & 60 & 60.01 & 0.036 & 100.01 & 0.060 \\
\hline & Volume of $0.4 \% \mathrm{NaNO}_{2}(1.0 \pm 0.1 \mathrm{ml})$ & 10 & 10.02 & 0.039 & 100.20 & 0.392 \\
\hline & & 60 & 60.03 & 0.053 & 100.05 & 0.089 \\
\hline & & 60 & 60.01 & 0.012 & 100.01 & 0.020 \\
\hline & Diazotization time & 10 & 10.06 & 0.041 & 100.60 & 0.415 \\
\hline & $(20 \pm 2 \mathrm{~min})$ & 60 & 60.11 & 0.069 & 100.18 & 0.115 \\
\hline & Diazo coupling time & 10 & 10.06 & 0.042 & 100.60 & 0.424 \\
\hline & $(30 \pm 2 \mathrm{~min})$ & 60 & 60.13 & 0.077 & 100.21 & 0.129 \\
\hline
\end{tabular}

CCP: Carisoprodol, SD: Standard deviation, RSD: Relative standard deviation

Table 6: Results of the analysis of CCP in tablet formulations

\begin{tabular}{|c|c|c|c|c|c|c|c|}
\hline Method & Labeled claim (mg) & Found* & SD & \% RSD & $\%$ recovery & $t$-value $e^{\$}$ & F-value $\$ \$$ \\
\hline \multirow[t]{2}{*}{1} & 250 & 250.03 & 0.040 & 0.016 & 100.012 & 0.097 & 3.195 \\
\hline & 350 & 350.06 & 0.052 & 0.015 & 100.017 & 0.116 & 4.616 \\
\hline \multirow[t]{2}{*}{2} & 250 & 249.973 & 0.023 & 0.094 & 99.989 & 0.465 & 2.353 \\
\hline & 350 & 350.015 & 0.032 & 0.092 & 100.004 & 0.988 & 3.082 \\
\hline \multirow[t]{2}{*}{$3^{@}$} & 250 & 250.09 & 0.025 & 0.071 & 100.036 & --- & --- \\
\hline & 350 & 249.91 & 0.034 & 0.067 & 99.964 & --- & --- \\
\hline
\end{tabular}

*Average of three determinations. ${ }^{\$}$ tabulated t value - $2.306 .{ }^{\$ \$}$ tabulated F value - 6.39. ${ }^{\circledR}$ Reference method. CCP: Carisoprodol, SD: Standard deviation, RSD: Relative standard deviation 


\section{CONCLUSION}

In the present investigation, there are two simple, rapid, cost-effective, accurate, precise, and robust spectrophotometric methods developed for the estimation of CCP, using $\mathrm{FeCl}_{3}, o$-phenanthroline, and PNA, $\mathrm{NaNO}_{2}$ as analytical reagents in bulk drug and tablet forms. The developed methods have the advantages over the reported spectrophotometric methods in being more sensitive, cost-effective, robust, precise, and accurate. Furthermore, the developed methods are inexpensive and do not require sophisticated instrumentation and elaborate treatments allied with chromatographic methods. Therefore, the proposed methods are applied for the routine analysis of CCP in quality control laboratories.

\section{ACKNOWLEDGMENTS}

The authors greatly acknowledge to Aurobindo Laboratories, Pvt., Ltd., India, for providing a gift sample of the drug. Authors also thankful to Acharya Nagarjuna University, Guntur, and NRI Institute of Technology, Pothavarappadu to provide facilities to carry out part of the research work.

\section{AUTHORS' CONTRIBUTION}

D Murali has developed and validated. G Purna Chandra Rao has computed and given suggestions to investigate the findings of this work. Both the authors discussed and contributed to the final manuscript.

\section{CONFLICTS OF INTEREST}

Authors have no conflicts of interest.

\section{REFERENCES}

1. Richart H. Tarascon Pocket Pharmacopoeia 2015 Deluxe Lab-Coat Edition. New York: Jones and Bartlett Learning; 2015. p. 1.

2. American Society of Health-System Pharmacists. AHFS Drug Information 2010. Bethesda, MD: American Society of Health-System Pharmacists; 2010. p. 1391.

3. Toth PP, Urtis J. Commonly used muscle relaxant therapies for acute low back pain: A review of carisoprodol, cyclobenzaprine hydrochloride, and metaxalone. Clin Ther 2004;26:1355-67.

4. Ralph L, Look M, Wheeler W, Sacks H. Double-blind, placebocontrolled trial of carisoprodol $250-\mathrm{mg}$ tablets in the treatment of acute lower-back spasm. Curr Med Res Opin 2008;24:551-8.

5. Skinner D, Mckemie SS. Quantitative determination of carisoprodol and its metabolites in equine urine and serum by liquid chromatographytandam mass spectrometry. Chromatographia 2004;59:61-7.

6. Kucharczyk N, Segelman FH, Kelton E, Summers J, Sofia RD, Mahrous $\mathrm{H}$, et al. Gas chromatographic determination of carisoprodol in human plasma. J Chromatogr 1986;377:384-90.
7. Kintz P, Mangin P, Lugnier AA, Chaumont AJ. A rapid and sensitive gas chromatographic analysis of meprobamate or carisoprodol in urine and plasma. J Anal Toxicol 1988;12:73-4.

8. Wang G, Huynh K, Barhate R, Rodrigues W, Moore C, Coulter C, et al. Validation of a new homogeneous immunoassay for the detection of carisoprodol in urine. J Anal Toxicol 2011;35:108-12.

9. Fisher J, Sherma J. Analysis of carisoprodol tablets by HPTLC with visible absorbance densitometry. Acta Chromatogr 2001;11:96-101

10. Laszlo P, Fryčák P, Nguyen V, Forster MJ. Mass spectrometric analysis of carisoprodol and meprobamate in rat brain microdialysates. J Mass Spectrom 2016;51:900-7.

11. Rohith T, Ananda S, Netkal MM. Method development and validation of carisoprodol and its impurities by ultra violet-high performance liquid chromatography. Adv Anal Chem 2013;3:15-9.

12. Ravi M, Veeraiah T, Ch VR. Spectrophotometric determination of carisoprodol in pure and pharmaceutical forms using triphenyl methane dyes. Int J Pharm Sci Res 2015;6:2936-43.

13. Rao KP, Srirangam GM, Ramana GV, Rao MC. Development of new visible spectrophotometric assay methods for atazanavir in pure and dosage forms. Res J Pharm Biol Chem Sci 2016;7:3042-50.

14. Satyanarayana PV, Madhavi AS. New spectrophotometric methods for the quantitative estimation of ezogabine in formulations. Int J Res Pharm Chem 2012;2:1093-8.

15. Jamilireddy K, Shanmukhakumar JV, Vardhan SV. Spectrophotometric methods for the determination of new oral penem (faropenem) in pure and in formulations. Chem Sci Transl 2013;2:936-40.

16. Abdellaziz LM, Hosny MM. Development and validation of spectrophotometric, atomic absorption and kinetic methods for determination of moxifloxacin hydrochloride. Anal Chem Insights 2011;6:67-78.

17. Kishor VN, Krishna KB, Ramana GV. Development of stability indicating spectrophotometric method for determination and validation of risperidonein formulation and bulk drug. Afro Asian J Sci Technol 2014;1:98-108.

18. Karad MD, Barhate VD. Spectrophotometric determination of an antimalarial drug chloroquine in bulk and pharmaceutical formulations. Int J Curr Pharm Res 2015;7:27-9.

19. Mallikarjuna H, Lokesh KS, Shivaprasad KH, Reddy KR. Sensitive spectrophotometric method for the determination of permetrexed disodium in pure and pharmaceutical formulations. Austin J Anal Pharm Chem 2014:1:1-6

20. Babu KB, Babu KM. New spectrophotometric methods for the quantitative estimation of refaximin in formulations. J Atoms Mol 2011; $1: 48-54$.

21. Mallikarjuna H, Lokesh KS, Shivaprasad KH, Reddy KR. Novel spectrophotometric methods for the assay of an antiepilepticoxcarbazepine. World J Pharm Pharm Sci 2014;3:815-31

22. Lakshmi PB, Krishna KB, Rambabu C. A sensitive spectrophotometri determination of ezetimibe in tablets using p-nitroaniline and ethylacetoacetate. Pharm Lett 2014;6:361-4.

23. ICH Validation of Analytical Procedures; Text and Methodology; Q2(R1), International Conference on Harmonization; 2005. 